2. Наказ ДПС від 22.06.2020 № 293 «Про затвердження програми управління людськими ресурсами державної податкової служби України на 2020 - 2023 роки» URL: https://tax.gov.ua/data/material/ 000/340/433469/11_Departament_31.08.2020.pdf

3. EU4PFM - EU for competitive, sound and thriving Ukraine. URL: https://eu4pfm.com.ua/

DOI https://doi.org/10.30525/978-9934-26-045-2-21

\title{
РОЛЬ КОНСУЛЬТАТИВНО-ДОРАДЧИХ ОРГАНІВ В ПРОЦЕСІ ПРИЙНЯТТЯ ВАЖЛИВИХ РІШЕНЬ НАВЧАЛЬНОГО ЗАКЛАДУ
}

\author{
Малахов А. А. \\ вчитель-методист, \\ директор
}

Миколаївської загальноосвітньої школи I-III ступенів № 57

імені Тараса Григоровича Шевченка

Миколаївської міської ради Миколаӥвської області

Клименко О. В.

вчитель-методист

Миколаӥвської загальноосвітньої иколи I-ІІІ ступенів № 57

імені Тараса Григоровича Шевченка

Миколаївської міської ради Миколаївської області

\author{
Ткачик Н. С. \\ вчитель-методист
}

Миколаївської загальноосвітньої школи I-III ступенів № 57

імені Тараса Григоровича Шевченка

Миколаївської міської ради Миколаївської області

м. Миколаїв, Україна

Розбудова відкритої, демократичної держави потребує розширення свідомої та компетентної участі громадськості у цьому процесі. Наразі в Україні склалася ситуація, коли вкрай необхідна реальна ефективна система взаємодії органів влади та громадськості. Саме участь громадськості в прийнятті управлінських та державних рішень дозво- 
лить підвищити ефективність здійснення владних функцій. I це має відбуватися на всіх етапах прийняття державних рішень: від підготовки пропозицій до виконання самих рішень та відповідного контролю за цим процесом.

Важливою організаційно-правовою формою здійснення впливу громадськості на прийняття нормативно-правових актів $\epsilon$ діяльність консультативно-дорадчих органів (далі консультативно-дорадчі органи - КДО), які утворюють для погодженого вирішення питань реалізації державної політики в певній сфері чи галузі, координації діяльності центральних, регіональних і місцевих органів публічної влади. Нині КДО забезпечують безпосередню взаємодію між громадськістю та органами публічної влади, яка відбувається здебільшого в консультативному форматі. Нестерович В.Ф. визначає поняття «консультативно-дорадчий орган», як колегіальну установу або орган, створений при органі публічної влади на постійній чи тимчасовій основі з метою забезпечення участі громадян в управлінні державними та суспільними справами шляхом проведення консультацій з громадськістю, попереднього обговорення питань, що належать до компетенції органу публічної влади, і здійснення громадського контролю за його діяльністю [2].

Правовою основою утворення та діяльності таких органів $\epsilon$ Конституція України, закони та інші нормативно-правові акти. Статус консультативно-дорадчого органу, повноваження, основні напрями i форми діяльності визначаються положенням про конкретний орган чи спеціальним актом відповідного державного органу - постановою, розпорядженням, наказом тощо. Порядок створення консультативнодорадчих органів визначається Постановою Кабінету Міністрів України «Питання консультативних, дорадчих та інших допоміжних органів, утворених Кабінетом Міністрів України» від 17 червня 2009 р. № 599.

Відповідно до статті 30 Закону України «Про повну загальну середню освіту» у закладах освіти та їх структурних підрозділах може діяти батьківське самоврядування. Батьківське самоврядування здійснюється батьками учнів як безпосередньо, так і через органи батьківського самоврядування, 3 метою захисту прав та інтересів учнів, організації їх дозвілля та оздоровлення, громадського нагляду (контролю) в межах повноважень, визначених цим Законом та статутом закладу освіти. Батьки мають право утворювати різні органи батьківського самоврядування (в межах класу, закладу освіти, за інтересами тощо). Батьки можуть розглядати будь-які питання і приймати рішення, 
крім тих, що належать до компетенції інших органів управління чи органів громадського самоврядування закладу освіти. Рішення органу батьківського самоврядування виконується батьками виключно на добровільних засадах [3].

В Україні існує практика створення КДО при закладах освіти. Найбільш поширеною формою КДО є: батьківські збори у школі; батьківський комітет; рада школи; благодійний фонд.

I. Моряк та В. Ласкою проаналізовано переваги на недоліки діяльності КДО в закладах освіти [1]:

Таблиця 1

\begin{tabular}{|c|c|c|}
\hline $\begin{array}{c}\text { Консультативно- } \\
\text { дорадчий орган }\end{array}$ & Переваги & Недоліки \\
\hline $\begin{array}{c}\text { Батьківські збори } \\
\text { у школі }\end{array}$ & $\begin{array}{c}\text { Можливість активно } \\
\text { впливати на життя школи; } \\
\text { врахування думки усіх } \\
\text { батьків, відчуття } \\
\text { згуртованості; доступ } \\
\text { батьків до інформації щодо } \\
\text { навчального процесу та } \\
\text { фінансово-технічного } \\
\text { забезпечення навчального } \\
\text { закладу. }\end{array}$ & $\begin{array}{c}\text { Формальність, позаяк } \\
\text { значна кількість батьків не } \\
\text { бере участі у батьківських } \\
\text { зборах; слабка } \\
\text { оперативність прийняття } \\
\text { рішень через те, що } \\
\text { загальні збори, як правило, } \\
\text { скликаються двічі на рік; } \\
\text { відсутність затвердженого } \\
\text { положення про батьківські } \\
\text { збори. }\end{array}$ \\
\hline $\begin{array}{c}\text { Батьківський } \\
\text { комітет }\end{array}$ & $\begin{array}{c}\text { Участь у вирішенні питань } \\
\text { розвитку матеріально- } \\
\text { технічної бази навчального } \\
\text { закладу та його } \\
\text { благоустрою; сприяння } \\
\text { соціально- правовому } \\
\text { захисту учасників } \\
\text { навчально- виховного } \\
\text { процесу; } \\
\text { скликання позачергових } \\
\text { загальних зборів чи } \\
\text { конференції батьків; } \\
\text { можливість створення } \\
\text { благодійних фондів, серед } \\
\text { повноважень яких: контроль } \\
\text { над надходженням і } \\
\text { розподілом коштів тощо. }\end{array}$ & $\begin{array}{c}\text { Має повноваження } \\
\text { виключно у межах класу } \\
\text { чи школи; часто виконує } \\
\text { роль збирачів готівки на } \\
\text { потреби класу чи школи; } \\
\text { відсутність статусу } \\
\text { юридичної особи, } \\
\text { відповідно не може } \\
\text { подавати заявки на участь } \\
\text { у грантах, конкурсах тощо; } \\
\text { небезпека входження до } \\
\text { батьківського комітету } \\
\text { людей, залежних від } \\
\text { адміністрації навчального } \\
\text { закладу; слабка система } \\
\text { комунікації між } \\
\text { «рядовими» батьками та } \\
\text { очільниками батьківських } \\
\text { комітетів. }\end{array}$ \\
\hline
\end{tabular}


Продовження таблиці 1

\begin{tabular}{|c|c|c|}
\hline Рада школи & $\begin{array}{c}\text { Складається пропорційно } \\
\text { з представників адміністрації, } \\
\text { батьків та учнів для вирішення } \\
\text { різних організаційних, } \\
\text { громадських, адміністративних } \\
\text { питань закладу; вносить } \\
\text { пропозиції щодо зміни типу, } \\
\text { статусу, визначає доцільність } \\
\text { вибору навчальних предметів } \\
\text { варіативної частини робочих } \\
\text { навчальних планів; бере участь у } \\
\text { засіданнях атестаційної комісії з } \\
\text { метою обговорення питань про } \\
\text { присвоєння кваліфікаційних } \\
\text { категорій вчителям; ініціює } \\
\text { розгляд кадрових питань та бере } \\
\text { участь у їхньому вирішенні; } \\
\text { організовує громадський контроль } \\
\text { за харчуванням і медичним } \\
\text { обслуговуванням учнів. } \\
\end{array}$ & $\begin{array}{c}\text { Більшість батьків не } \\
\text { володіє інформацією про } \\
\text { можливість висувати свою } \\
\text { кандидатуру до ради } \\
\text { школи; відсутня } \\
\text { інформація про діяльність } \\
\text { ради школи (засідання, } \\
\text { прийняті рішення); } \\
\text { підконтрольність } \\
\text { адміністрації школи. }\end{array}$ \\
\hline $\begin{array}{c}\text { Благодійний } \\
\text { фонд }\end{array}$ & $\begin{array}{c}\text { Домінуюча роль батьків у } \\
\text { прийнятті рішень; статус } \\
\text { юридичної особи; можливість: } \\
\text { подати заявки на участь у грантах } \\
\text { та конкурсах; запровадити } \\
\text { стипендії для кращих учнів, } \\
\text { кращих вчителів тощо; } \\
\text { організовувати подорожі, } \\
\text { екскурсії; брати участь у } \\
\text { співфінансуванні розвитку } \\
\text { проектів учнів, їхніх ідей чи } \\
\text { винаходів; впливати на } \\
\text { визначення пріоритетності } \\
\text { проведення ремонтних робіт. }\end{array}$ & $\begin{array}{l}\text { Неготовність батьків до } \\
\text { самоорганізацї та } \\
\text { відповідальності; } \\
\text { гіпотетичні труднощі з } \\
\text { адмініструванням } \\
\text { благодійних фондів; } \\
\text { слабка обізнаність батьків } \\
\text { з профільним } \\
\text { законодавством та } \\
\text { нормативними актами; } \\
\text { повноваження здебільшого } \\
\text { лише у межах фінансово- } \\
\text { господарської діяльності } \\
\text { навчального закладу. }\end{array}$ \\
\hline $\begin{array}{l}\text { Батьківська } \\
\text { громадська } \\
\text { організація }\end{array}$ & $\begin{array}{c}\text { Зареєстрована юридична особа; } \\
\text { розширення можливостей та } \\
\text { інструментів впливу; контроль за } \\
\text { використанням бюджетних коштів, } \\
\text { виділених на навчальний заклад; } \\
\text { можливість обміну досвіду } \\
\text { з міжнародними організаціями, } \\
\text { проведення місцевих, } \\
\text { всеукраїнських та міжнародних } \\
\text { заходів. }\end{array}$ & $\begin{array}{c}\text { Недостатня кількість } \\
\text { активних батьків, готових } \\
\text { працювати у форматі } \\
\text { громадської організації. }\end{array}$ \\
\hline
\end{tabular}


I хоча КДО в закладах освіти безпосередньо не приймають рішення, вони мають значний влив на прийняття рішень адміністрацією закладу. КДО виявляють та пропонують шляхи, методи вирішення певних проблем, адміністрація закладу ознайомлюється з ними та потім впроваджують їх. Рішення КДО мають рекомендаційний характер і $\epsilon$ обов'язковими для розгляду адміністрацією закладу. Рішення адміністрації закладу, прийняте за результатами розгляду пропозицій КДО, не пізніше ніж у десятиденний строк після його прийняття в обов'язковому порядку доводиться до відома членів КДО та громадськості шляхом його оприлюднення на офіційному веб-сайті закладу та в інший прийнятний спосіб. Інформація про прийняте рішення має містити відомості про врахування пропозицій КДО або причини їх відхилення.

Протягом 2016-2020 років КДО при Миколаївській загальноосвітні школі I-III ступенів №57 імені Т.Г.Шевченка було надано до адміністрації закладу 112 пропозицій та зауважень, з них 105 $(93,75 \%)$ було враховано при прийнятті рішень, про що свідчить наступна діаграма:

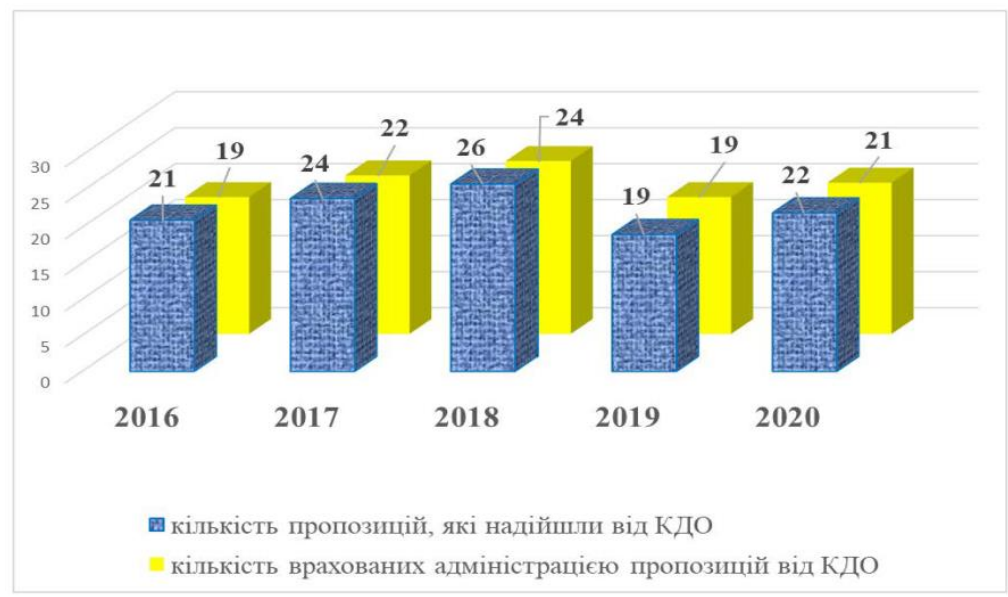

Утвердження консолідованої демократії як засадничого принципу суспільно-політичного устрою та важливого чинника реалізації євроінтеграційних процесів України неможливо без забезпечення дієвої взаємодії органів управління з громадськістю у процесі підготовки та прийняття важливих рішень щодо розвитку закладу. 
Лiтература:

1. Батьківське самоврядування в закладах освіти. URL: https://uhp.org.ua/wp-content/uploads/2016/11/fondy-03-10-new.pdf (дата звернення: 05.03.2021).

2. Поняття «консультативно-дорадчий орган» як категорія конституційного права. Нестерович В.Ф. URL: http://elar.naiau.kiev.ua/ bitstream/123456789/2848/1/ПОНЯТТЯ\%20»КОНСУЛЬТАТИВНОДОРАДЧИЙ\%20ОРГАН».pdf (дата звернення: 05.03.2021).

3. Про повну загальну середню освіту : Закон України від 01.08 .2020 p. 463-IX / Верховна Рада України. URL: https://zakon.rada.gov.ua/laws/show/463-20\#Text (дата звернення: 05.03.2021).

DOI https://doi.org/10.30525/978-9934-26-045-2-22

\title{
CARBON TAX MANAGEMENT IN THE EASTERN PARTNERSHIP COUNTRIES: MINIMIZING FINANCIAL RISKS OF EUROPEAN GREEN DEAL AND COVID-19 CRISIS
}

\author{
Moroz O. V. \\ Candidate of Physical and Mathematical Sciences, \\ Senior Research Fellow \\ Kyiv, Ukraine
}

The imperfection of the financial market determines the limitations of financial instruments for low-carbon investments [1, p. 19]. Constrained access to finance in many developing countries may limit their capacity to develop effective stimulus packages for the post-pandemic recovery [2, p. 6]. Actual tasks for approximation to international and EU mechanisms of functioning of the financial services system in Eastern Partnership $(E a P)$ countries and other developing still need to be solved by Governments, including the fulfillment of the Paris Agreement obligations [3].

Effective use of carbon taxes with another instruments could be a key solution to the problem of limited access to finance, exacerbated by the effects of Covid-19, and especially in the developing countries. That comes from unanimous independent conclusions of $\operatorname{OECD}[2$, p. 2, 6, 11], the World Bank [4, p. 4, 11], the International Monetary Fund [1, p. 8]; according to research of the Centre for Climate Change Economics and 